\title{
Mapping Precambrian Aquifer Architecture in Fractured Hydrogeological Setting with Vertical Electrical Sounding
}

\author{
Folorunso Adetayo F. ${ }^{1,2}$, Ariyo Stephen O. ${ }^{3} \&$ Ayolabi Elijah A. ${ }^{2}$ \\ ${ }^{1}$ College of Marine Geosciences, Ocean University of China, Qingdao, China \\ ${ }^{2}$ Department of Geosciences, University of Lagos, Lagos, Nigeria \\ ${ }^{3}$ Department of Earth Sciences, Olabisi Onabanjo University, P. M. B. 2002, Ago-Iwoye, Nigeria \\ Correspondence: Folorunso Adetayo F., College of Marine Geosciences, Ocean University of China, Qingdao \\ 266003, China. Tel: 86-15806-520-225. E-mail: detayof@yahoo.com
}

Received: May 2, 2013 Accepted: August 15, 2013 Online Published: August 19, 2013

doi:10.5539/v5n3p202 URL: http://dx.doi.org/10.5539/v5n3p202

\begin{abstract}
Electrical resistivity sounding was employed to delineate different water bearing layers and their architectural parameters. Sixty Vertical Electrical Soundings (VES) were obtained in the built-up area of Olabisi Onabanjo University campus to map out variations in subsurface resistivity, which was used to determine aquifer parameters favourable for groundwater development. Interpretation of electrical sounding data helps in determining the resistivity and thickness of aquifers, aquifer and overburden thicknesses and depth to the basement. We employ a lithology-based hydrogeological model with definite boundary to classify the apparent resistivity. In this model, range of electrical resistivity values were assigned to different layers based on field observation and knowledge of the geology of the area. In all, five litho-units were delineated besides the topsoil, which are: clay with resistivity range of 25-53 $\Omega \mathrm{m}$; clayey sand/sandy clay with resistivity range of $122-440$ $\Omega \mathrm{m}$; weathered layer with $62-119 \Omega \mathrm{m}$; fractured basement with $208-667 \Omega \mathrm{m}$ and resistivity above $720 \Omega \mathrm{m}$ were taken as fresh basement. From the initial lithologic-based model, we developed 2D model that conceptualized aquifer architecture and bedrock topography along the major traverses obtained in the area. Also, Isopac map reveals that the overburden is thicker in the western half while the $2 \mathrm{D}$ model and structural map clearly show undulating bedrock topography made up of bedrock ridge with elevations of $127.0-170.0 \mathrm{~m}$ and bedrock depressions with elevation of $97.0-123 \mathrm{~m}$. Derived Geo-electric parameters revealed that aquifer quality increases as we move northward, though recommended aquifers cut across all the area survey. Based on the study, we recommended VES stations with good overall qualities to be developed to productive water-supply tube wells.
\end{abstract}

Keywords: Precambrian aquifer, VES, aquifer thickness, hydrogeological model, aquifer overburden and bedrock depression

\section{Introduction}

Groundwater is a preferred water source in many instances because, having been filtrated by the soil, its quality is generally good. Also, it is readily available and often regarded as the only source of freshwater available due to its better spatial extension and distribution. It also represents $97 \%$ of the planet's fresh water (Singh et al., 2006). The study site, Olabisi Onabanjo University was founded on $27^{\text {th }}$ July, 1982 and opened to academic work on $31^{\text {st }}$ January 1983 at a temporary site. The place continued to host the entire university until 1998, when the then Vice-Chancellor moved some faculties and administrative staff to the University Main Campus, profoundly called 'Permanent Site or PS'. Following this 'historic movement' more faculties were moved in to join the existing ones. This leads to increase population of water-dependent people and activities on the campus. Initially, water supply to the campus was by water tanker (lorry). However, this failed to meet the yearnings of both staff and students who depend on the resource for daily activities; hence, the need for extensive hydrogeological campaign of the entire campus. Mapping aquifer architectures in the area becomes imperative to understand the groundwater condition in detail. The main focus of the present work is to provide information on the subsurface lithology, aquifer architecture and groundwater occurrence for hydrogeologic interpretation from the geoelectric resistivity measurements and the geological mapping reported earlier by Folorunso et al. (2013). At the end, hydrogeological information of the campus will be readily available for consultation in the eventual readiness of 
the authority concerned to develop groundwater for use in the campus.

The global growing population and civilization have resulted in an increasing consumption and demand for water for several routine activities. Since surface water sources are limited in time and space cum the high cost of developing a dam for municipal use, attentions have been shifted to groundwater over the years. For this reason, improvement of geophysical methods applicable in groundwater exploration becomes imperative to reduce cost and safe time. The use of electrical resistivity methods has earned an important place in the history of groundwater exploration since 1970s owing to the availability of computers to process and analyze the data (Reynoids, 1997). Despite hi-tech improvement in 2D and 3D resistivity tomography in imaging the subsurface, VES still remains a method to reckon with in hydrogeological study (for example Atwia et al., 2013), perhaps, on the account of its relatively cost effectiveness, simplicity of data acquisition, processing and interpretation and deeper depth of penetration. Many authors have employed this method to solve problems relating to groundwater exploration, groundwater monitoring, and saline water intrusion, environmental and engineering surveys and in the study of the direction of contaminant plume, (Osella \& Lascano, 2002; Adepelumi et al., 2008; Folorunso et al., 2012; Atwia et al., 2013).

\subsection{Topography, Geology and Hydrogeology}

The study area lies between longitudes $3^{0} 52^{1}$ and $3^{0} 53^{1}$ and latitudes $6^{0} 54.5^{1}$ and $6^{0} 56^{1}$ and $3.5 \mathrm{~km}$ south-western part of Ago-Iwoye Township, Figure 1c and d. Topography is rugged generally undulating with a range of relatively steep sided hills running north-south in the western part of the area forming a ridge.

The local geology belongs to the Precambrian basement complex of Nigeria which is one of the three major litho-petrological components that make up the geology of Nigeria; others being the younger granite and the sedimentary basins (Figure 1b). The basement complex comprising the nearly triangular complex in the west, that extents and continues westwards into neighbouring Benin Republic (Dahomey); the nearly circular complex in the north and the elongated basement eastward to Cameroon. Geologically, the basement complex of Nigeria comprises four distinct lithologies recognized as migmatite-gneiss complex, metasedimentary and metavolcanic rocks (The Schist Belts), the Pan-African granitoids (The Older Granites), and the undeformed acid and basic dykes (Annor, 1998; Rahaman, 1989; Caby \& Boesse, 2001; Rahaman, 2006; Obaje, 2009).

Precisely, Folorunso et al. (2013) reported that the local geology comprises four distinct rock units which are porphyroblastic (augen) gneiss, hornblende-biotite gneiss, banded gneiss and quartz schist belonging to the migmatite-gneiss complex and the Schist Belt (Figure 1a). The authors also noted that numerous faults and joint systems mapped on rock outcrops have created fractures and secondary porosity in the gneiss complex of the area.

Hydrogeologically, the study area falls to the category of a hard rock environment where semi-weathered/weathered and fractured rocks form aquifers. Here, the storage of water mainly depends upon the thickness of the weathered and fractured zones which often leads to poor groundwater withdrawal because of the absence of porosity and permeability. Thus, groundwater in this area is governed primarily by the thickness of the weathered material, and the extent, size, openness, and interconnections of fractures. Recoverable groundwater in basement complex often occurs in weathered mantle (regolith), (Wright \& Burgess, 1992). Laterite often developed in the weathered profile and thus can be locally important as a dependable source of groundwater especially when typified by honeycombs structures. Deeper fractures within the basement rocks are another important source of groundwater, particularly where the weathered zone is thin or absent. Fractures and fracture zones have long been recognized to control groundwater flow regimes (Rayner et al., 2007). They are often more hydraulically conductive than the surrounding host rock, though not all are open to fluid flow, but their hydraulic properties differ with fracture aperture, intensity, orientation, connectivity and infill material (Birgersson et al., 1993). These deep fractures are tectonically controlled and can sometimes provide supplies of up to one or even five litres per second of water as remarked by Chilton and Foster (1995). Incidentally, geological and structural mappings of the area show high extent of surface fracture for the rock outcrop and the strike of the structural elements was found to conform to the flow direction of surface water in the area (Folorunso et al., 2012, 2013). This on its own is a good clue that the basement rock under the area is well fractured. Our work was then directed to map out the fractured basement and the weathered mantle (regolith) as good aquifer units capable for possible hydrogeological development. 


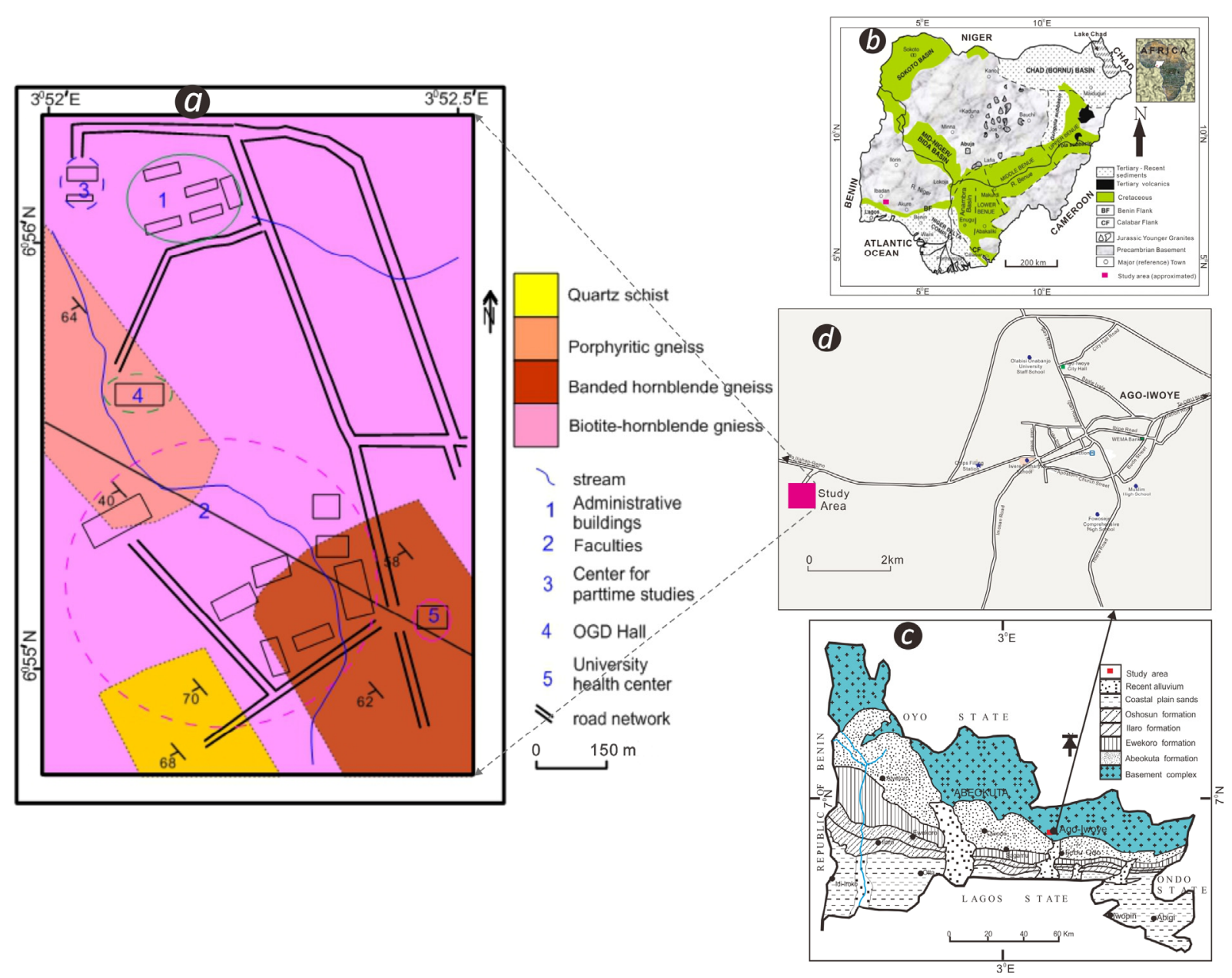

Figure 1. Geological maps showing a) local geology of the study area (after Folorunso et al., 2013); b) Nigeria geological map; $\mathrm{c}$ and d) regional political boundary reflecting the position of the study area to Ago-Iwoye

Township

\section{Materials and Methods}

\subsection{Vertical Electrical Sounding}

Sixty (60) Vertical Electrical Sounding (VES) stations using Schlumberger electrode array were established along access roads and around buildings in the study area (Figure 2) to enhance adequate coverage of the area. The resistivity measurements were made by using IRIS Instruments Syscal Junior Terrameter. The equipment is a high-powered, fully automated resistivity meter for dc electrical surveys. It has been used extensively in groundwater exploration, environmental studies, civil engineering and structural geology investigation. Measurements were made by injecting current into the ground through two current electrodes $\mathrm{AB}$ and measuring the resulting voltage difference at the potential electrodes $\mathrm{MN}$, while the current electrode separation $\mathrm{AB}$ are spatially increased about the mid-point $(\mathrm{O})$ from $1.0 \mathrm{~m}$ to $100 \mathrm{~m}$ until the length of the array $(\mathrm{L})$ is exhausted (Figure 3). The potential electrodes (MN) were gradually increased in steps starting from $0.5 \mathrm{~m}$ to $10 \mathrm{~m}$ to obtain a measurable potential difference.

The measured data were inspected, processed and interpreted automatically by using the geoelectrical 1-D inversion software WinGLinK (2007). This is an automatic computerized iteration software used to obtain true resistivity and depth from the apparent resistivity data obtained at each VES location. Sounding curves were plotted as apparent resistivities versus electrode spacing $(\mathrm{AB} / 2)$ for Schlumberger sounding array. It is user-friendly, highly interactive, graphically oriented, forward and inverse modeling program. Representative resistivity sounding curves obtained after inversion are shown in Figure 4. Due to the geological complexity of the study site, near-surface inhomogeneities (which reflected in the wide variations in resistivities of the top soil), and topographical variation, which create 2D effects; an hydrogeological model was thus developed using the estimated resistivities and thickness, and its equivalent 2D effect shown across many VES stations. 


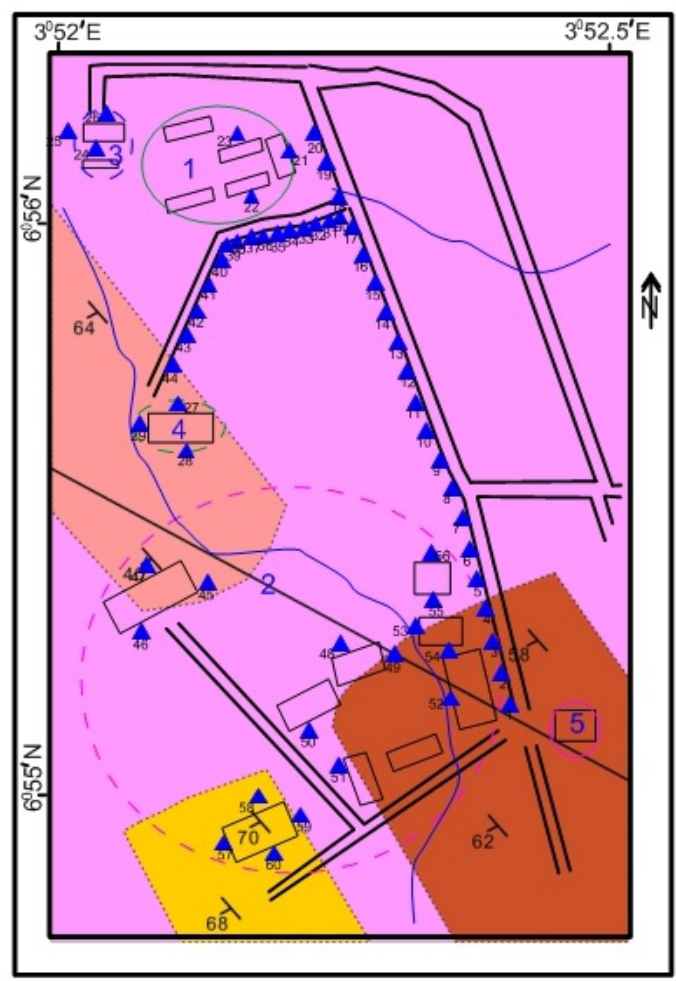

(a)

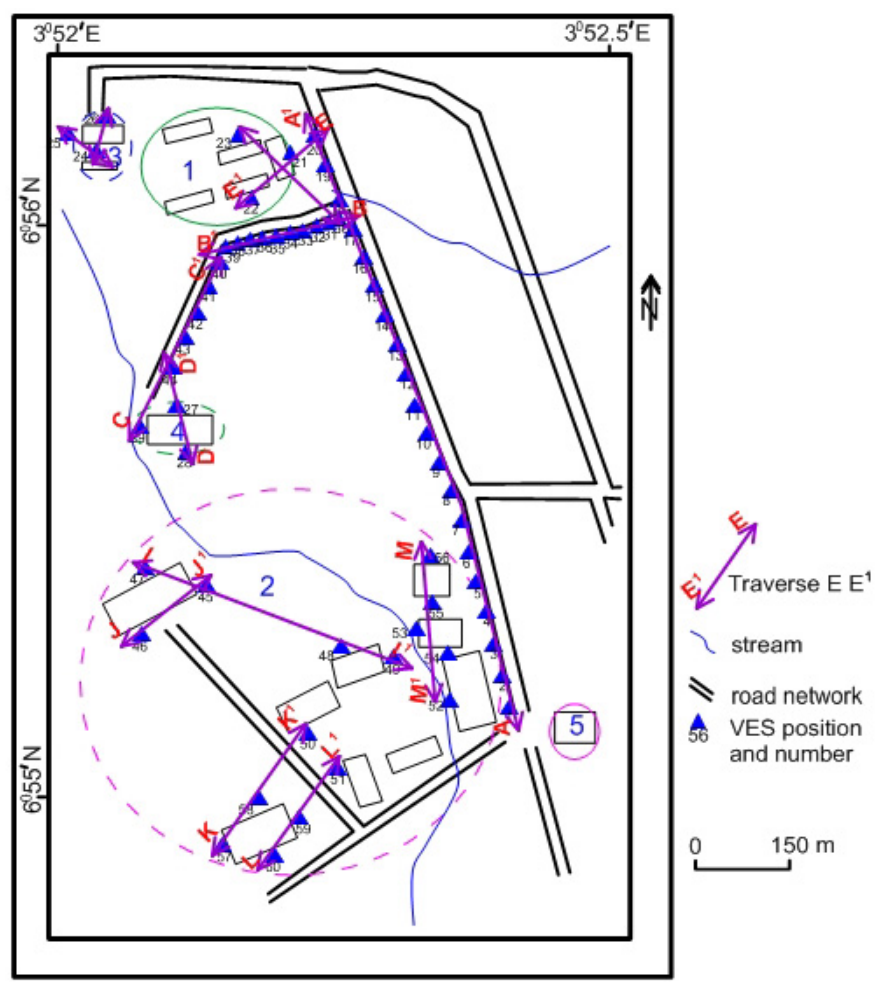

(b)

Figure 2. Data acquisition map (a) relative to the geological map; (b) showing the traverses

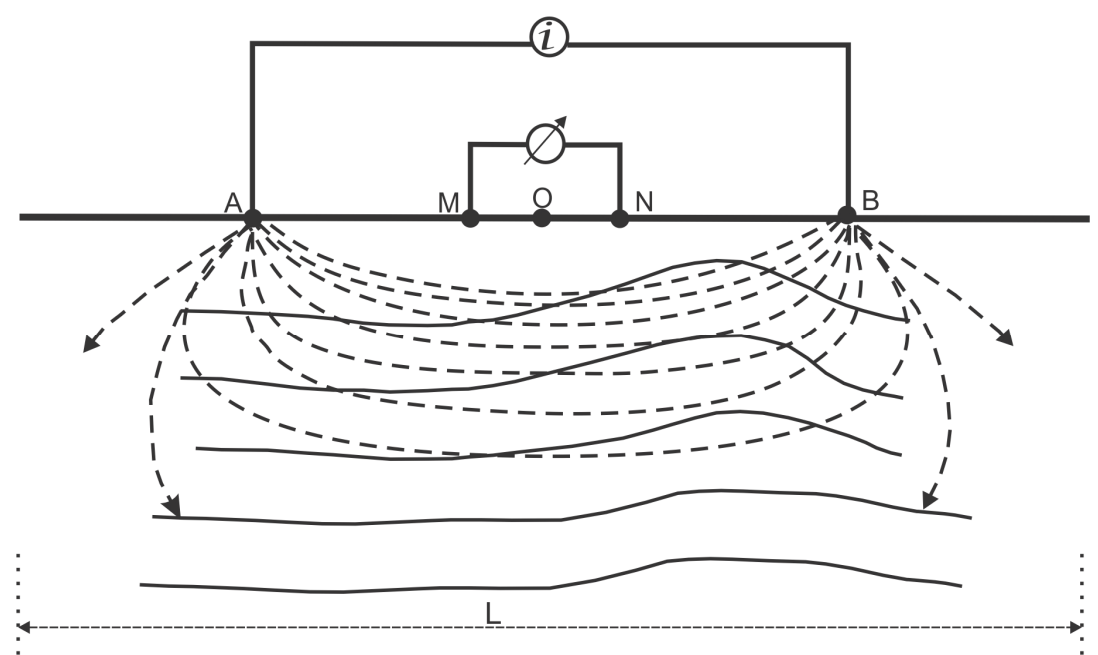

Figure 3. Electrode configuration of a typical four electrodes array 


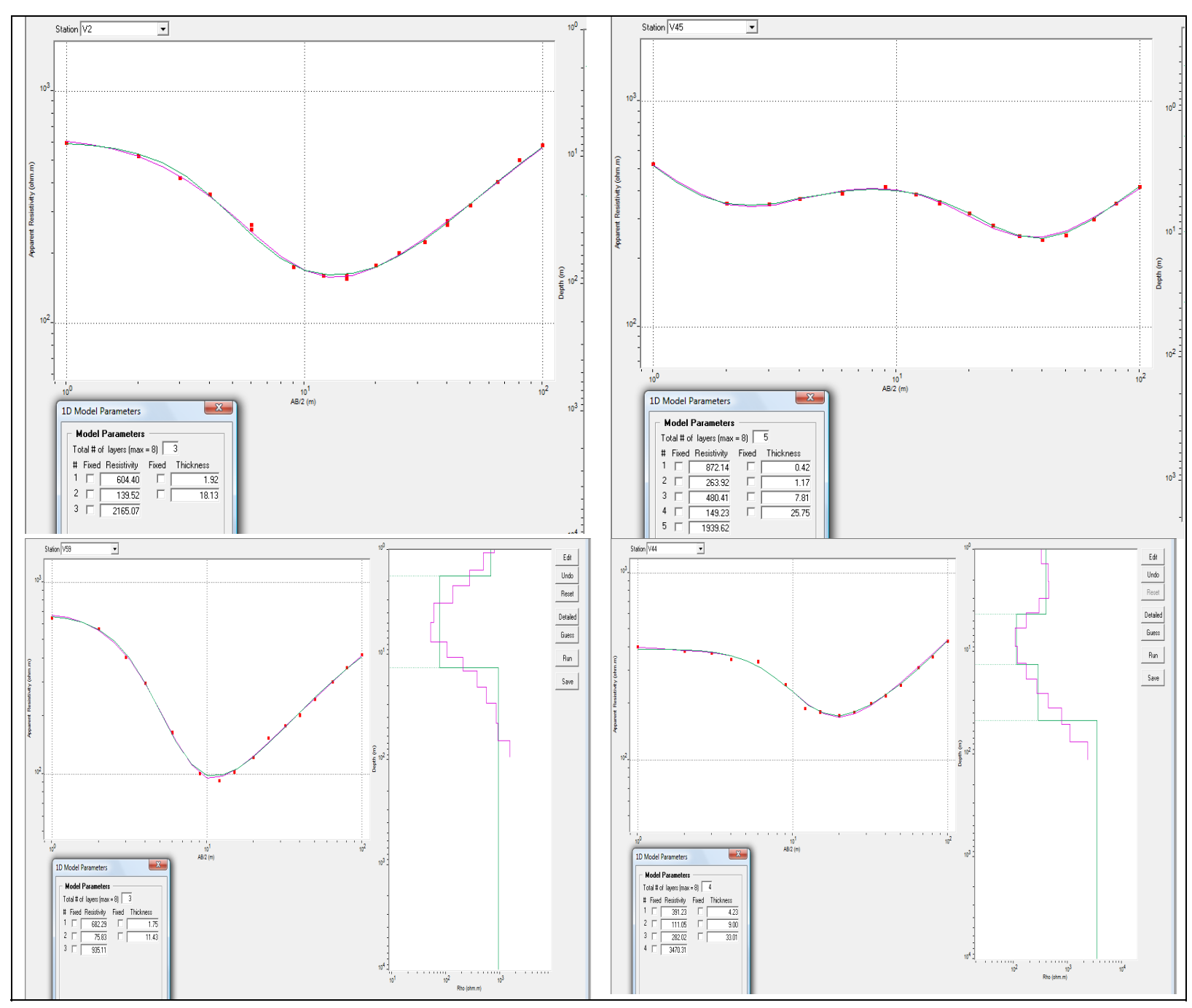

Figure 4. Representative VES resistivity-distance models for the area

\section{Results and Discussion}

\subsection{Electrical Resistivity Result}

The results of the computer modeling for the sounding stations are presented in the Table 1. We employ a lithology-based hydrogeological model with definite boundary to classify the apparent resistivity. In this model, geological units were marked by a range of resistivity values. In all, five litho-units were delineated besides the topsoil. Clay is delineated with resistivity range of $25-53 \Omega \mathrm{m}$; clayey sand/sandy clay with resistivity range of $122-440 \Omega \mathrm{m}$; weathered layer with 62-119 $\Omega \mathrm{m}$; fractured basement with $208-667 \Omega \mathrm{m}$ and resistivity above 720 $\Omega \mathrm{m}$ were taken as fresh basement.

\subsection{The Precambrian Aquifer Units}

We delineate three kinds of aquifers using our lithology-based hydrogeological model. The first is the clayey sand/sandy clay aquifer variably underlain by basement or fractured basement. Where it is underlain by fractured basement, we consider the clay/sandy clay litho-unit as a good aquifer recharge overburden to the fractured basement aquifer. We also notice that a few shallow hand-dug wells found in the area tap water from this aquiclude. Whereas where it directly overlies the basement rock, it represents the residual aquifer derived from the basement, which makes a good aquifer if the thickness is appreciable. The examples of the second scenario are found in VES stations 3, 39, 44 and 45 having 22-35 m thickness (Figures 5 and 6).

The second aquifer unit is the weathered mantle or regolith represented with resistivity range of $62-119 \Omega \mathrm{m}$. In most cases, it lies directly atop the fresh basement rock, which implies that the unit is a residual soil of the basement rock. Marked by thickness range of 3-29 m, this unit lacks good overburden thickness needed for 
groundwater development in most stations (examples: VES stations 1, 14-16, 19, 20, 40-45 and 52-Figures 5 and 6). At stations 21, 24, 33 and 44 however, the weathered aquifer is considered good having thickness above $20 \mathrm{~m}$ and appreciable overburden thickness.

The third aquifer is the fractured basement resting on the unaltered basement rock and varying in resistivities from 208-667 $\Omega \mathrm{m}$. It is overlain by sand/sandy clay which serves as overburden for the aquifer, while it lies directly on the basement rock. The fracture rock was marked with good layered and overburden thicknesses (for example: VES stations 26, 38, 46, 54, 55 and 57, see Figures 5 and 6) needed for good groundwater development in secondary-derived porous media.

Because of the 2D nature of study area, its geological complexity, topographical variation and near-surface inhomogeneities (reflected in variations in resistivities of the top soil) we model the 2D subsurface resistivity using layer resistivity and thickness across many VES stations as shown in Figure 6. This aptly depicts the aquifer geometry and bedrock topography. The understanding of aquifer distribution under the study area is crucial for groundwater development planning as the campus expands. From our model, we generated aquifer distribution map shown in Figure 7. The map helps to understand the influence of deformational tectonic events that accompanied Pan African orogeny on the aquifers. The aquifers were possibly formed in response to the deformational force thereby assuming the same NW-SE trending as reported by Folorunso et al. (2013). The weathered layer aquifer is restricted to the NW and SW of the area; while sandy clay/clayey sand aquifers are mainly at the center. The fractured basement aquifer is situated in the east and west. Generally, aquifer quality appears to increase northward.

Table 1. Summary of VES results in the study area

\begin{tabular}{|c|c|c|c|c|}
\hline VES Points & Layer Resistivity $\rho_{1} / \rho_{2} / \rho_{3} / \ldots \rho_{\mathrm{n}}(\Omega \mathrm{m})$ & Depth $\mathrm{D}_{1} / \mathrm{D}_{2} / \mathrm{D}_{3} / \ldots \mathrm{D}_{\mathrm{n}}$ & Aquifer thickness (m) & $\begin{array}{l}\text { Aquifer } \\
\text { Type }\end{array}$ \\
\hline 1 & $837 / 89 / 1270$ & $1.14 / 9.62$ & 8.35 & WL \\
\hline 2 & $604 / 140 / 2165$ & $1.92 / 20.05$ & 18.13 & $\mathrm{CSC}$ \\
\hline 3 & $351 / \mathbf{1 4 1} / 1299$ & $1.47 / 36.10$ & 34.73 & $\mathrm{CSC}$ \\
\hline 4 & $211 / \mathbf{1 1 7} / 1457$ & $3.36 / 23.83$ & 20.47 & WL \\
\hline 5 & $59 / 503 / \mathbf{1 3 2} / 2354$ & $0.45 / 2.69 / 18.94$ & 15.35 & $\mathrm{CSC}$ \\
\hline 6 & $491 / 270 / \mathbf{4 5 0}$ & $0.54 / 3.17$ & & FR \\
\hline 7 & $158 / 346 / 667$ & $1.51 / 8.29$ & & FR \\
\hline 8 & $125 / 50 / 454$ & $0.51 / 7.37$ & & FR \\
\hline 9 & $425 / \mathbf{1 7 3} / 1052$ & $0.96 / 12.78$ & 11.82 & $\mathrm{CSC}$ \\
\hline 10 & $393 / \mathbf{1 5 9} / 869$ & $0.94 / 13.24$ & 12.3 & $\mathrm{CSC}$ \\
\hline 11 & $426 / 199 / 831$ & $1.44 / 11.18$ & 9.74 & $\mathrm{CSC}$ \\
\hline 12 & $466 / 141 / 440 / 1223$ & $0.77 / 4.81 / 21.48$ & 16.67 & $\mathrm{CSC}$ \\
\hline 13 & $679 / \mathbf{1 5 6} / 828$ & $0.41 / 4.67$ & 4.26 & $\mathrm{CSC}$ \\
\hline 14 & 732/119/584 & $0.92 / 4.69$ & 3.77 & FR \\
\hline 15 & $537 / \mathbf{1 1 5} / 3110$ & $0.91 / 17.49$ & 16.58 & WL \\
\hline 16 & $1350 / \mathbf{9 0} / 2112$ & $0.63 / 15.54$ & 14.91 & WL \\
\hline 17 & $177 / 37 / 492$ & $1.16 / 8.85$ & & FR \\
\hline 18 & $133 / 391 / \mathbf{4 1} / 813$ & $0.77 / 1.76 / 11.34$ & 9.58 & Clay \\
\hline 19 & $484 / \mathbf{1 0 6} / 1660$ & $0.82 / 18.38$ & 17.56 & WL \\
\hline 20 & $259 / 72 / 720$ & $1.47 / 11.47$ & 11.0 & WL \\
\hline 21 & $310 / \mathbf{8 3} / 1384$ & $1.25 / 22.18$ & 20.93 & WL \\
\hline 22 & $418 / 53 / \mathbf{3 4 8}$ & $0.54 / 12.64$ & & FR \\
\hline 23 & 291/82/923 & $2.39 / 17.51$ & 15.12 & WL \\
\hline 24 & $462 / 279 / 91 / 1517$ & $0.81 / 7.46 / 37.69$ & 30.23 & WL \\
\hline 25 & $316 / 139 / 82 / 912$ & $3.38 / 9 / 78 / 19.85$ & 10.07 & WL \\
\hline 26 & $367 / 195 / 428 / 740$ & $0.42 / 9.08 / 43.75$ & 34.67 & FR \\
\hline 27 & $624 / 134 / 51 / 3547$ & $1.72 / 9.12 / 24.77$ & 15.65 & Clay \\
\hline
\end{tabular}




\begin{tabular}{|c|c|c|c|c|}
\hline VES Points & Layer Resistivity $\rho_{1} / \rho_{2} / \rho_{3} / \ldots \rho_{\mathrm{n}}(\Omega \mathrm{m})$ & Depth $\mathrm{D}_{1} / \mathrm{D}_{2} / \mathrm{D}_{3} / \ldots \mathrm{D}_{\mathrm{n}} \quad(\mathrm{m})$ & Aquifer thickness (m) & $\begin{array}{l}\text { Aquifer } \\
\text { Type }\end{array}$ \\
\hline 28 & $1623 / 33 / \mathbf{1 4 5} / 823$ & $0.74 / 2.98 / 12.09$ & 9.1 & $\mathrm{CSC}$ \\
\hline 29 & $905 / \mathbf{1 0 3} / 900$ & $0.83 / 17.10$ & 16.27 & WL \\
\hline 30 & 744/110/49/1708 & $0.62 / 2.64 / 20.82$ & 2.02 & Clay \\
\hline 31 & $993 / \mathbf{1 0 5} / 1257$ & $0.87 / 17.22$ & 16.35 & WL \\
\hline 32 & $887 / 87 / 2001$ & $1.13 / 19.77$ & 18.64 & WL \\
\hline 33 & $371 / 44 / \mathbf{1 1 8} / 1501$ & $1.38 / 5.66 / 29.51$ & 23.85 & WL \\
\hline 34 & $683 / 45 / 755$ & $1.14 / 9.29$ & 8.15 & Clay \\
\hline 35 & $493 / 79 / 839$ & $0.92 / 16.28$ & 15.36 & WL \\
\hline 36 & $871 / 49 / 514$ & $0.87 / 7.72$ & & FR \\
\hline 37 & $433 / 44 / 417$ & $1.01 / 7.07$ & & FR \\
\hline 38 & $1049 / 174 / 332$ & $0.78 / 16.59$ & & FR \\
\hline 39 & $1347 / 313 / \mathbf{1 4 8} / 742$ & $0.65 / 10.03 / 23.64$ & 13.61 & $\mathrm{CSC}$ \\
\hline 40 & $456 / \mathbf{8 8} / 720$ & $0.71 / 12.15$ & 11.44 & WL \\
\hline 41 & $600 / \mathbf{8 3} / 880$ & $1.27 / 15.43$ & 14.16 & WL \\
\hline 42 & $719 / 82 / 1057$ & $1.64 / 19.94$ & 18.3 & WL \\
\hline 43 & $805 / 99 / 841$ & $0.92 / 15.77$ & 14.85 & WL \\
\hline 44 & $391 / 111 / 282 / 3470$ & $4.23 / 13.23 / 46.24$ & 33.01 & $\mathrm{CSC}$ \\
\hline 45 & $872 / 264 / 480 / \mathbf{1 4 9} / 1934$ & $0.42 / 1.59 / 9.4 / 35.15$ & 25.75 & $\mathrm{CSC}$ \\
\hline 46 & $469 / 101 / 568 / 1716$ & $3.82 / 28.92 / 41.58$ & 12.66 & FR \\
\hline 47 & $330 / \mathbf{4 5} / 1399$ & $2.3 / 11.15$ & 8.85 & Clay \\
\hline 48 & $883 / 74 / 1615$ & $1.97 / 14.08$ & 12.11 & WL \\
\hline 49 & $395 / \mathbf{1 0 3} / 1481$ & $2.63 / 13.19$ & 10.56 & WL \\
\hline 50 & $825 / \mathbf{1 4 4} / 786$ & $1.31 / 8.14$ & 6.83 & $\mathrm{CSC}$ \\
\hline 51 & $540 / 62 / 815$ & $0.81 / 8.74$ & 7.93 & WL \\
\hline 52 & $301 / \mathbf{8 5} / 796$ & $0.83 / 4.24$ & 3.41 & WL \\
\hline 53 & 246/49/955 & $2.36 / 12.11$ & 9.75 & Clay \\
\hline 54 & $241 / 154 / \mathbf{2 0 8} / 3428$ & $1.31 / 5.84 / 35.85$ & 30.01 & FR \\
\hline 55 & $774 / 122 / 451$ & $1.45 / 13.24$ & 11.79 & FR \\
\hline 56 & $514 / \mathbf{1 3 1} / 841$ & $1.74 / 14.1$ & 12.36 & $\mathrm{CSC}$ \\
\hline 57 & $340 / 117 / 398$ & $2.03 / 10.39$ & & FR \\
\hline 58 & 291/112/71/790 & $2.36 / 8.56 / 23.21$ & 14.65 & WL \\
\hline 59 & $1021 / 349 / \mathbf{1 0 6} / 3178$ & $1.31 / 6.66 / 21.26$ & 14.26 & WL \\
\hline 60 & $121 / \mathbf{2 5} / 1906$ & $1.01 / 13.05$ & 12.04 & Clay \\
\hline
\end{tabular}

CSC - clayeysand/sandyclay; WL - weathered layer; FR - fractured rock; Aquifer type refers to various geologic layers constituting the aquifer. 


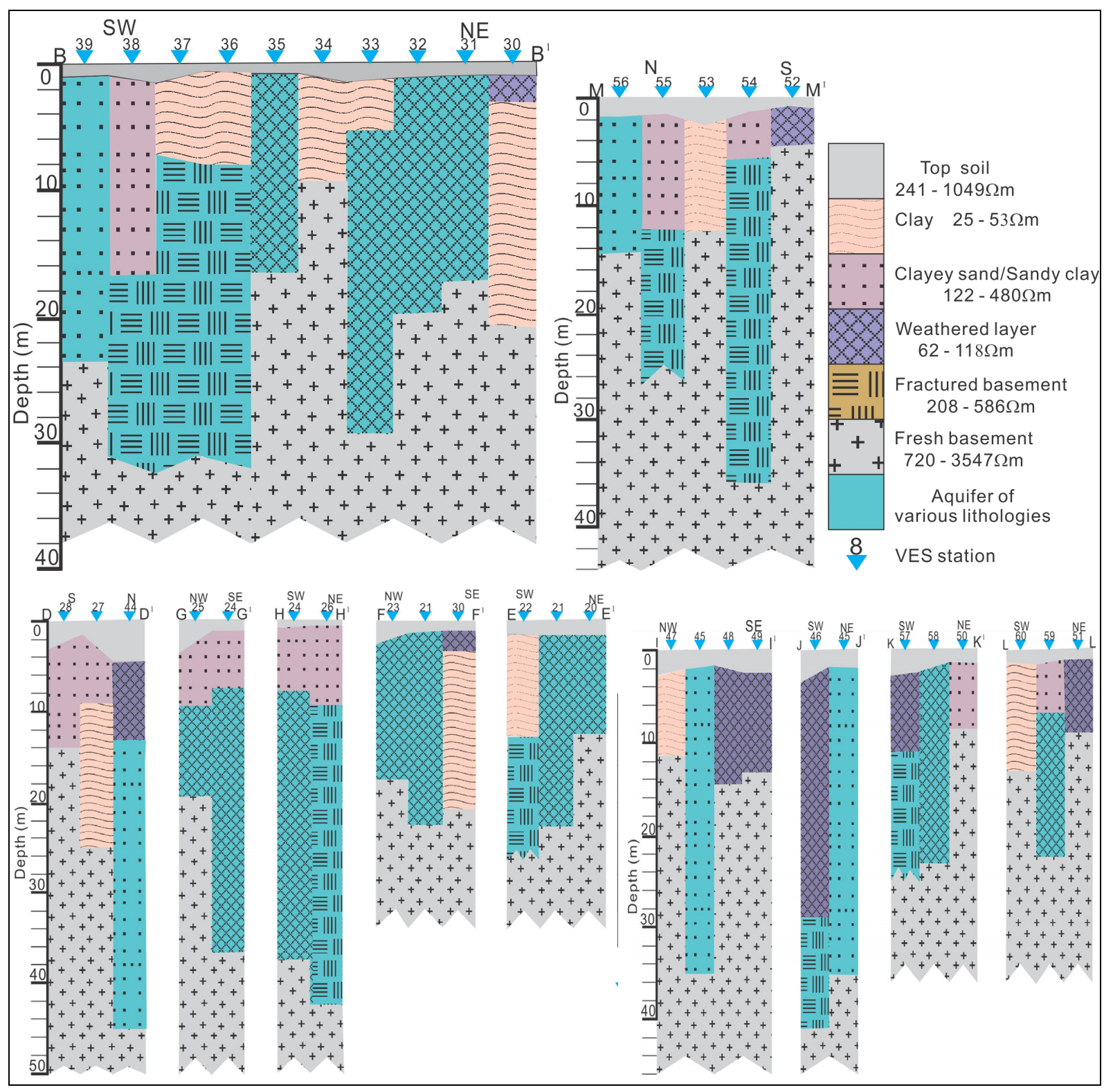

Figure 5. Geoelectric cross-sections of traverses shown in Figure 2b 


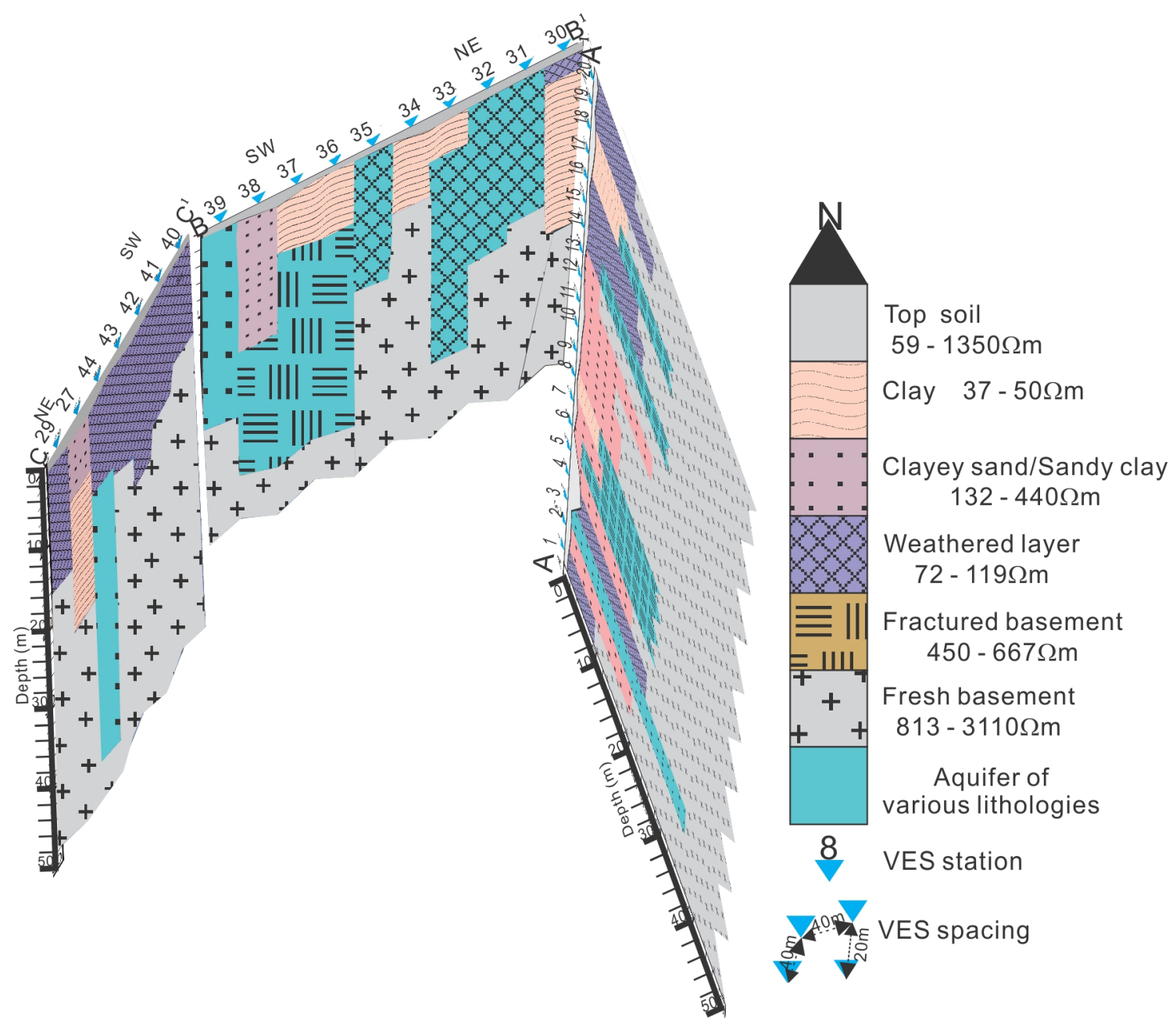

Figure 6. 2D model of subsurface under traverses $\mathrm{AA}^{1}, \mathrm{BB}^{1}$ and $\mathrm{CC}^{1}$ reflecting discontinuity of aquifer in fractured hydrogeological setting where aquifer depends mainly on secondary derived porosity and permeability. Aquifers of different lithologies (fractures basement, weathered mantle and sandy clay/clayey sand) are indicated in blue while similar lithologies without good aquifer quality are indicated as ordinary geo-electric layer 


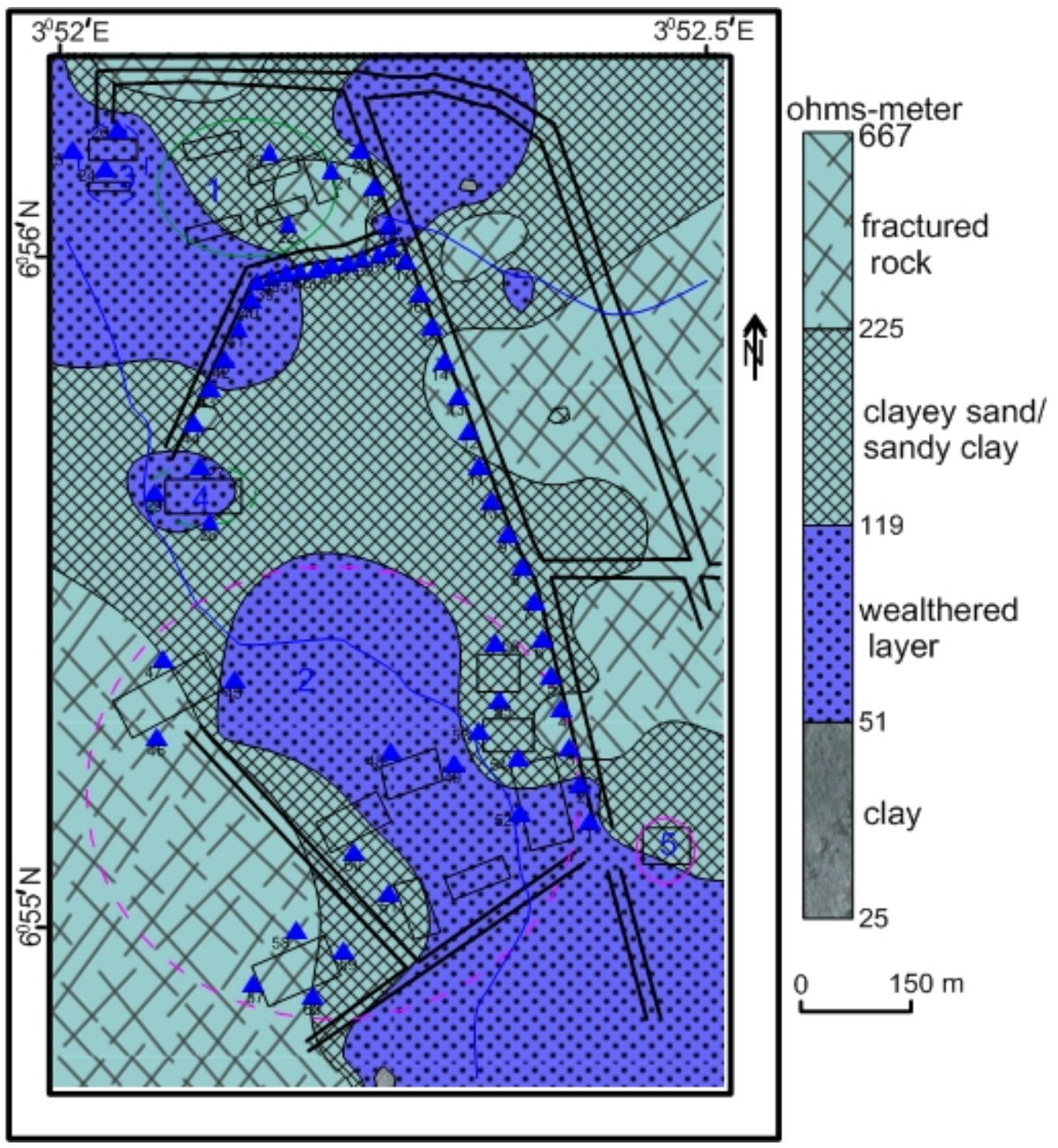

Figure 7. Aquifer distribution map of the area. Note the NW-SE trending of the aquifer which agrees with the direction of the Pan Afracan Oregeny mapped and reported on rock outcrops in the area by Folorunso et al.

(2013)

\section{Geoelectric Parameters}

\subsection{Isopach Map of the Overburden}

The Overburden here is considered as all the materials above the fresh bedrock at each of the VES stations. This is contoured as an overburden map (Figure 8) and reflects variation in overburden thickness within the study area. This is a very important parameter in hydrogeology and environmental studies. Averagely thick overburden is required in basement aquifers which depend mainly on secondary porosity, while the thick overburden doubles as aquifer recharge source. On the environmental side, a very thin overburden implies that the aquifer may not be adequately protected in the eventual pollution of the surface because the pollutant might easily percolate through the thin layer to the groundwater. Based on the overburden thickness, the study area is grouped into very thick overburden cover of 30.0-47 m within a depression towards the west; moderately thick cover of $15 \mathrm{~m}-30 \mathrm{~m}$ and thick overburden cover of 3.17-19.85 m on the bedrock ridges towards the east as shown in Figure 8. 


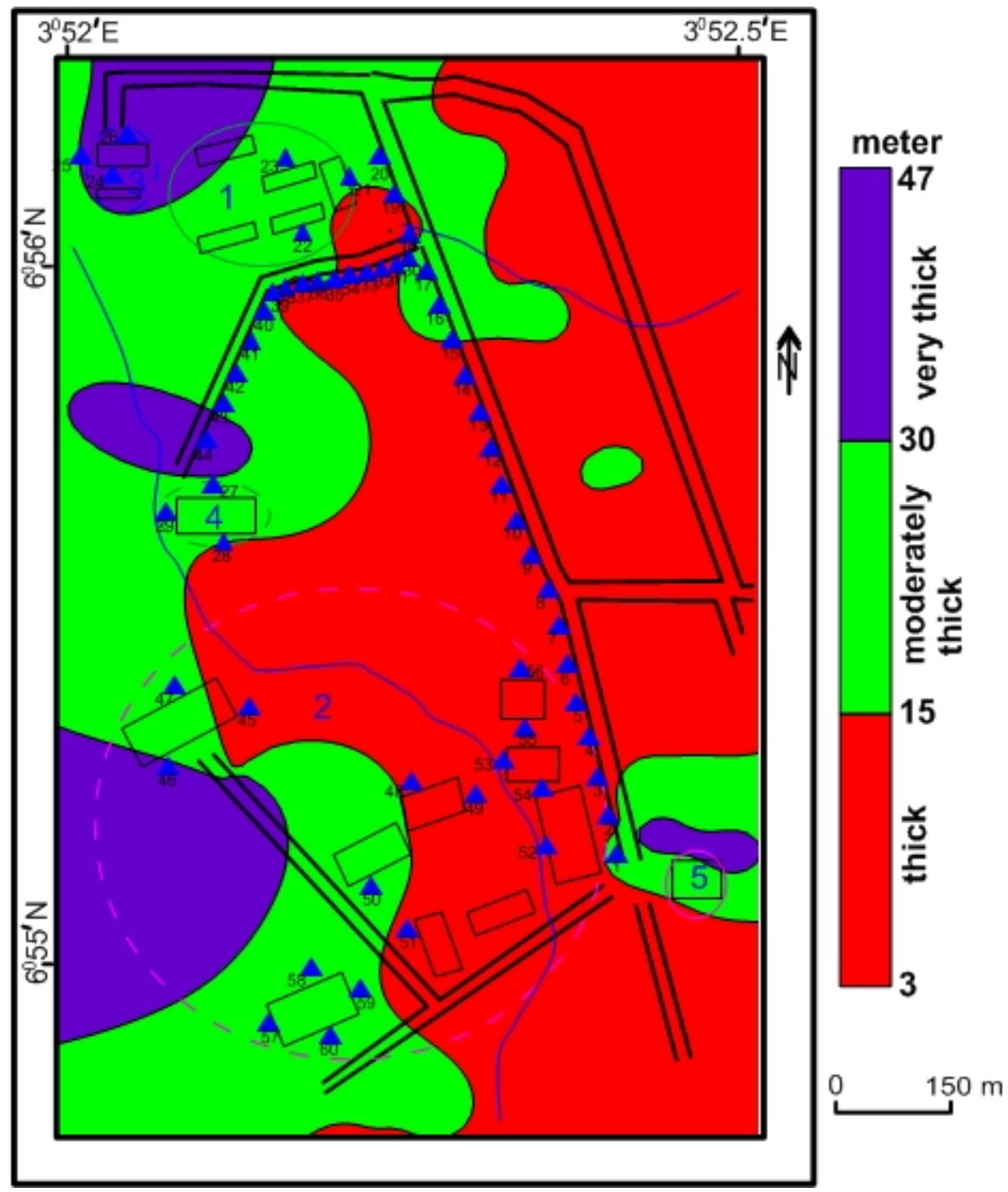

Figure 8. Isopach map of the overburden

\subsection{Aquifer Thickness}

Thickness of aquifer determines the groundwater yield and storability, which is a function of quantity. It is another parameter necessary to determine the sustainability of a water borehole. The variation of the waterbearing layers thickness in the study area is shown in Figure 9, indicating three zones of thickness - thin (below $10 \mathrm{~m})$, moderately thick $(10-20 \mathrm{~m})$ and very thick (above $20 \mathrm{~m}$ ) water-bearing zones. We noticed that most of the aquifers are thicker than 10 meters, especially two-third from north to south. Weathered layer to the north are very thick (mostly above $20 \mathrm{~m}$, compare with Figure 7) but very thin to the south. Almost all the sandy clay and fractured aquifers fall to the moderately thick aquifer type. 


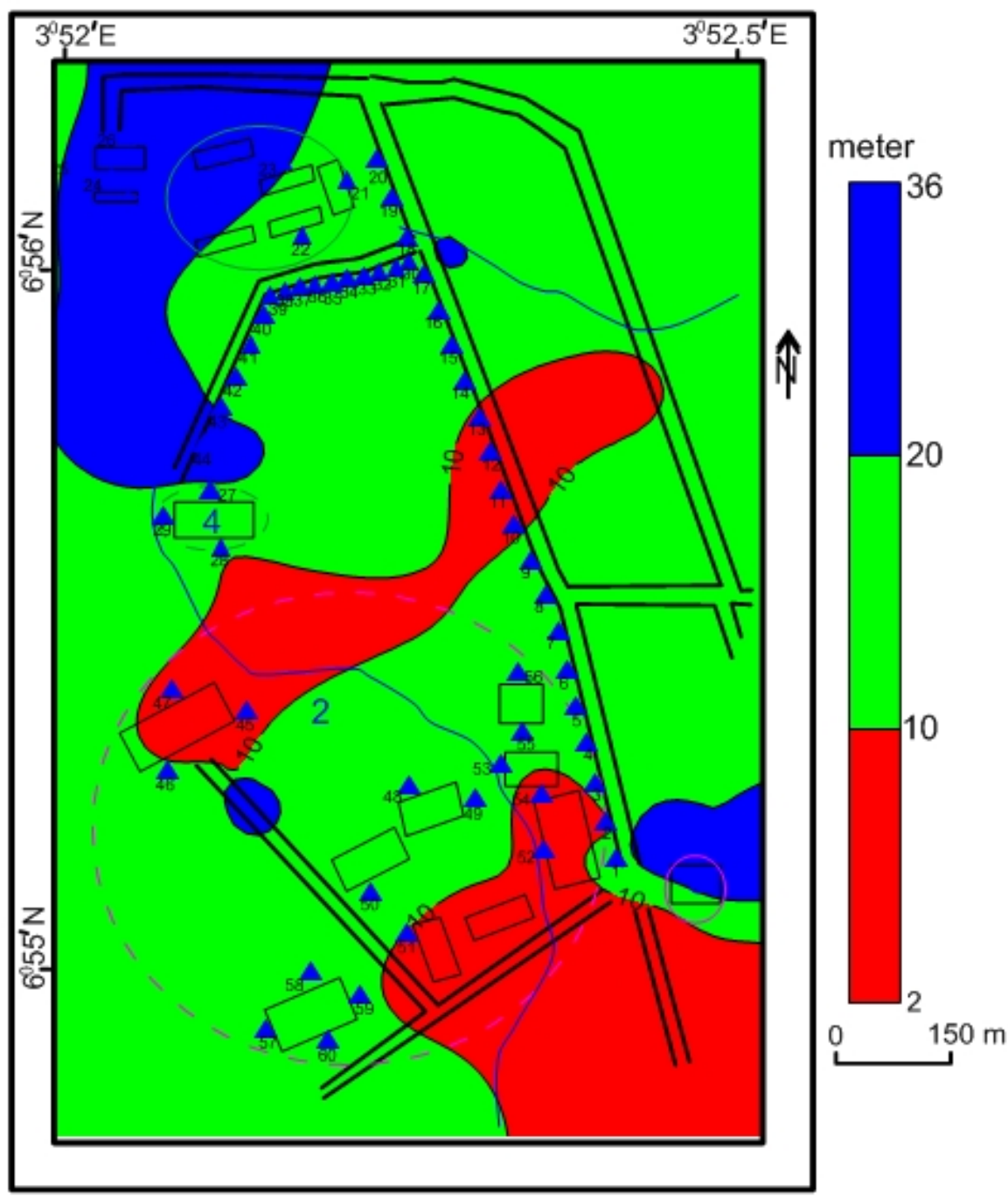

Figure 9. Aquifer thickness map overlain with data acquisition map

\subsection{Structural Map}

This refers to the topography of the bedrock which could be derived when the overall thicknesses of the materials before the basement are removed. This is also an important parameter as it shows the variation in basement relief in the study area. Bedrock depression is usually a region of groundwater accumulation. There are two approaches to this. One is the determination of elevation beneath each of the VES stations by removing the overburden thickness from the surface elevation at the VES stations. Surface elevations were determined from the topographic map of the area as prepared by Geological Survey of Nigeria (1964). The second one is using negative values of the depths to bedrock to produce a 3-D view of the bedrock relief (Figure 10). The relief map is a reflection of the bedrock topography and shows bedrock ridges and depression within the area. The area is divided into ridges $(\mathrm{R})$ and depression (D). The bedrock elevations of 127.0-170.0 m were taken as bedrock ridges while those of $97.0-123.0 \mathrm{~m}$ were taken as bedrock depressions. 


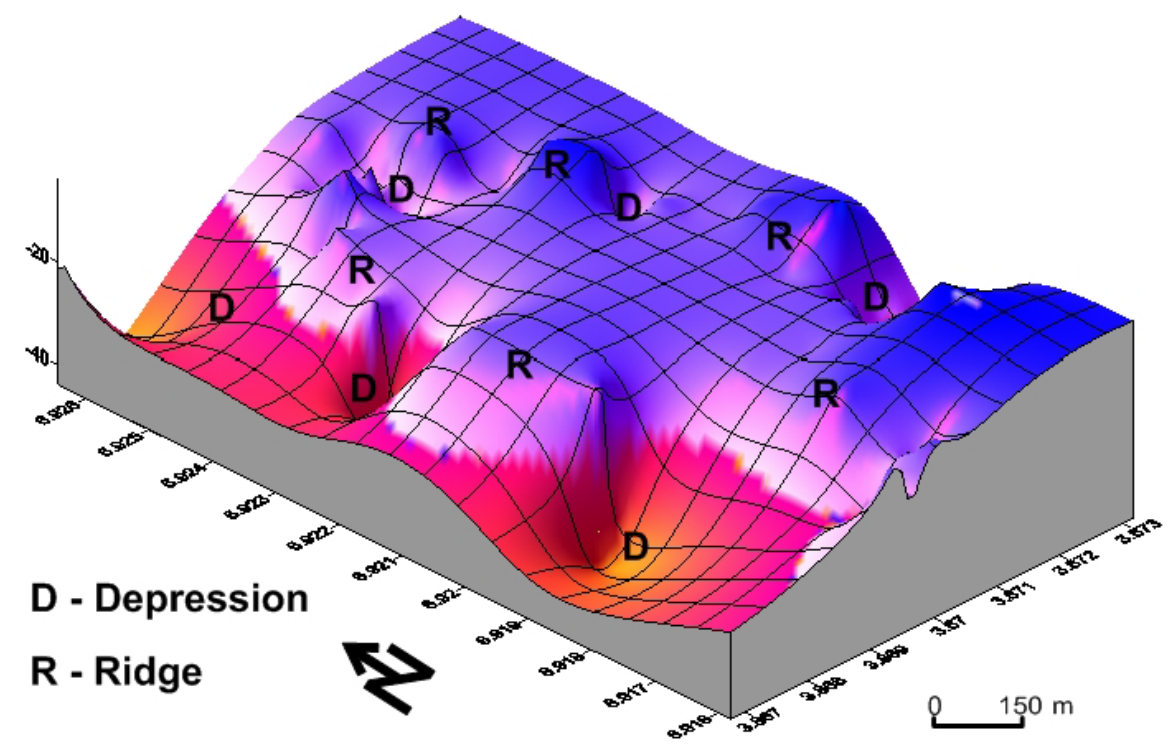

Figure 10. Structural map showing bedrock relief in the area

\section{Conclusions and Recommendations}

Three aquifers can be identified in the study area, weather mantle aquifer, sandy clay/clayey aquifer and fractured basement aquifer. The areal distribution of the aquifers cum architectural framework was determined in this study. The thicknesses of these aquifers range from 22 to $35 \mathrm{~m}$ for the clayey sand/ sandy clay aquifer and 3 to $29 \mathrm{~m}$ for the weathered mantle aquifer. In most cases, the fractured basement aquifer has infinity thickness while thickness ranges from 12 to $32 \mathrm{~m}$ in other VES stations. Generally, aquifer architectures reveal that aquifers towards the northern part portend better qualities than those in the southern part, having good aquifer and overburden thickness capable of sustaining groundwater development for the campus.

Based on the results of this study, it is recommended that:

1) The baseline data generated from this study should be taken as guide in drilling water-supply tube wells for the community when in future a sustainable network of groundwater will be developed for the campus use.

2) Considering all parameters examined, VES stations 44 (sandy clay aquifer), 24 and 33 (weathered mantle aquifer); 26, 38, 46, 54 and 55 (fracture rock aquifer) could be developed to productive boreholes with varying depths (for example: VES 24, 26, 44 and 46 to $32 \mathrm{~m}, 40 \mathrm{~m}, 40 \mathrm{~m}$ and $38 \mathrm{~m}$ respectively) according to each VES point.

3) It is also recommended that near-surface layers should be cased to avoid pollution from anthropogenic source and to avoid borehole collapse. Depths of casings will invariably vary according to the VES point.

4) Further electrical resistivity surveys should be carried out prior any drilling operations especially in a case where the proposed site is not adequately covered by the present study.

5) More than one tube-well will be needed to satisfy the water need of the campus community, and from this study, at least all area covered has one or two stations recommended for drilling.

\section{Acknowledgements}

Funding support from Olabisi Onabanjo University research grant is acknowledged by the first author. The work is an integral part of his MSc dissertation. We are grateful to our students, Iyiola, Dixon and Kadejo for their assistance during the fieldwork. We also acknowledge Professor A.I. Olayinka of the premier University of Ibadan, dissertation external examiner, whose comments help to improve this paper.

\section{References}

Adepelumi, A. A., Ako, B. D., Ajayi, T. R., Afolabi, O., \& Omotoso, E. J. (2008). Delineation of saltwater intrusion into the freshwater aquifer of Lekki Penninsula, Lagos, Nigeria. Environ Geol, 56(5), 927-933. http://dx.doi.org/10.1007/s00254-008-1194-3 
Annor, A. E. (1998). Structural and Chronological Relationship between the low Grade Igara Schist and its Adjoining Okere Migmatite-Gneiss Terrain in the Precambrian Exposure of Southwestern Nigeria. Jour. Min. Geol., 34(2), 187-196.

Atwia, M. G., Abu-Heleika, M. M., \& El-Horiny, M. M. (2013). Hydrogeochemical and Vertical Electrical Soundings for Groundwater Investigations, Burg El-Arab Area, Northwestern Coast of Egypt. $J$ Afri Earth Scis, 80, 8-20. http://dx.doi.org/10.1016/j.jafrearsci.2012.11.001

Birgersson, L., Moreno, L., Neretnieks, I., Widen, H., \& Agren, T. (1993). A tracer migration experiment in a small fracture zone in granite: Water Res Research, 29, 3867-3878. http://dx.doi.org/10.1029/93WR02340

Caby, R., \& Boesse, J. M. (2001). Pan African Nappe System in southwest Nigeria: The Ife-Ilesha Schist Belt. $J$ Afri Earth Sci., 33, 211-225. http://dx.doi.org/10.1016/S0899-5362(01)80060-9

Chilton, P. J., \& Foster, S. S. D. (1995). Hydrogeological Characterization and water supply Potential of Basement Aquifers in Tropical Africa. Hydrogeol J., 3(1), 36-49. http://dx.doi.org/10.1007/s100400050061

Folorunso, A. F., Ayolabi, E. A., \& Ariyo, S. O. (2013). Geological mapping, petrological study and structural analysis of precambrian basement complex rocks in part of Ago-Iwoye Southwestern Nigeria. Interl Res $J$ Geolo and Mining (IRJGM), 3(1), 19-30.

Folorunso, A. F., Ayolabi, E. A., Ariyo, S. O., \& Oyebanjo, I. O. (2012). Fault presence under a failing building complex mapped by electrical resistivity tomography. Mineral Wealth, Greece, 166, 47-55.

Obaje, N. G. (2009). Geology and mineral resources of Nigeria (p. 221). Springer Dordrecht Heidelberg. http://dx.doi.org/10.1007/978-3-540-92685-6

Osella, A., de la Vega, M., \& Lascano, E. (2002). Characterization of a contaminant plume due to a hydrocarbon spill using geoelectrical methods. J Env. \& Eng. Geophysics., 7(2), 78-87. http://dx.doi.org/10.4133/JEEG7.2.78

Rahaman, M.A. (2006). Nigeria's Solid Minerals Endowment and Sustainable Development. In O. Oshin (Ed.), The Basement Complex of Nigeria and its Mineral Resources: A Tribute to Prof. M.A.O. Rahaman.

Rahaman, M. A. (1989). Review of the Basement Geology of South-Western Nigerian. In C. A. Kogbe (Ed.), 2nd Ed. of Geology of Nigeria (pp. 39-56). Nigeria: Rock View, Jos.

Rayner, S. F., Bentley, L. R., \& Allen, D. M. (2007). Constraining Aquifer Architecture with Electrical Resistivity Imaging in a Fractured Hydrogeological Setting. J Env Eng Geophy, 12(4), 323-335. http://dx.doi.org/10.2113/JEEG12.4.323

Reynoids, J. M. (1997). An Introduction to Applied and Environmental geophysics (pp. 41-49). New York: John Wiley \& Sons.

Rhyjov, A., \& Shevnin, V. (2002). Theoretical Calculation of Rocks Electrical Resistivity and some Examples of Algorithm's Application. In Proceedings of the Symposium on the Application of Geophysics to Engineering and Environmental Problems. http://dx.doi.org/10.4133/1.2927161

Singh, K. K. K., Singh, A. K., Singh, K. B., \& Singh, A. (2006). 2D Resistivity Imaging Survey for Siting Water supply Tube wells in Metamorphic Terrains: A case study of CMRI Campus, Dhanbad, India. The Leading Edge, 25(12), 1458-1460. http://dx.doi.org/10.1190/1.2405329

Wright, E. P., \& Burgess, W. G. (1992). The Hydrogeology of Crystalline Basement Aquifers in Africa. Geological Society Special Publication, 66, 1-27.

Winglink. (2007). Integrated interpretation software. Version 2.20.01. Geosystem corporation, Milan.

\section{Copyrights}

Copyright for this article is retained by the author(s), with first publication rights granted to the journal.

This is an open-access article distributed under the terms and conditions of the Creative Commons Attribution license (http://creativecommons.org/licenses/by/3.0/). 